\title{
Lumen
}

Selected Proceedings from the Canadian Society for Eighteenth-Century Studies

\section{The Progress of Another Error: Anne Finch's 'The Spleen'}

\section{Chantel Lavoie}

Volume 18, 1999

Representations of Time in the XVIIIth Century

Le temps et ses représentations au dix-huitième siècle

URI : https://id.erudit.org/iderudit/1012370ar

DOI : https://doi.org/10.7202/1012370ar

Aller au sommaire du numéro

Éditeur(s)

Canadian Society for Eighteenth-Century Studies / Société canadienne d'étude du dix-huitième siècle

ISSN

1209-3696 (imprimé)

1927-8284 (numérique)

Découvrir la revue

Citer cet article

Lavoie, C. (1999). The Progress of Another Error: Anne Finch's 'The Spleen'.

Lumen, 18, 107-117. https://doi.org/10.7202/1012370ar

Copyright (c) Canadian Society for Eighteenth-Century Studies / Sociéte canadienne d'étude du dix-huitième siècle, 1999
Ce document est protégé par la loi sur le droit d'auteur. L'utilisation des services d'Érudit (y compris la reproduction) est assujettie à sa politique d'utilisation que vous pouvez consulter en ligne.

https://apropos.erudit.org/fr/usagers/politique-dutilisation/ 


\title{
8. The Progress of Another Error: Anne Finch's 'The Spleen'
}

\author{
What art thou, Spleen, which every thing dost ape? \\ Thou Proteus, to abus'd Mankind, \\ Who never yet thy hidden Cause cou'd find, \\ Or fix Thee to remain in one continu'd shape; \\ Still varying thy perplexing Form...
}

With this query and complaint begins 'The Spleen', a pindaric ode composed by Anne Finch, Countess of Winchilsea (1661-1720), sometime before June, 1701, when the poem first appeared in a printed collection of verse by several hands. This was twelve years before the publication of Finch's own volume, Miscellany Poems on Several Occasions, by which time the 150-line ode had gained recognition as a skillful composition that dealt intelligently with a popular ailment. Before and after the publication of her book, printings of shorter poems by Finch were attributed to 'the author of The Spleen.' It is often noted that 'The Spleen' itself was frequently reprinted, though how frequently has still not been pinned down. Certainly the ode survived its author better than a great many works by other minor writers of the period. Shortly after Finch's death, for example, Dr. William Stukely thought her poem accurate enough to include as a supplement to a medical treatise on the symptoms of and remedies for the spleen. ${ }^{2}$ A century later, William Wordsworth regretted the poem's continued pre-eminence. 'The most celebrated of these poems', he remarked to Alexander Dyce of Finch's 1713 volume, 'but far from the best, is "The Spleen."'33 Wordsworth sought to emphasize those sublime elements in Finch's poetry which might be seen as anticipating his own work. Germaine Greer takes exception to Wordsworth's assumptions in her article 'Wordsworth and Winchilsea: The Progress of an Error. ${ }^{4}$ I take my title from Greer in this paper, but my own concern is with the print history of the 'celebrated', but insufficiently considered poem that launched Anne Finch's fame. In the first section of this paper, I present bibliographical evidence that Finch's ode appeared in print in the early eighteenth century more often than has been assumed. In the second half, I offer an interpretation of 
this evidence in light of Finch's reputation as a poet and as a member of a community of writers.

Some of Finch's writings were circulating among friends as early as the 1680s, while she was Maid of Honour to Mary of Modena, yet there is no indication in early correspondence that 'The Spleen' was composed before 1701 . Not only was some of her minor verse circulated in manuscript, but it is now known that lyrics by Finch were printed as early as the 1680s in pro-Stuart anthologies, and examples of her religious verse can be found in miscellanies of the 1690s. ${ }^{5}$ These early publications were sparse, however, and 'The Spleen' is undoubtedly the poem that contributed most to establishing the poet's fame, attracting an appreciative audience when it appeared in print. The publication in print of a poem that has been circulating only in manuscript seems to fix the text and to lend it solidity. As the extant printings multiply, however, this fixed state becomes again less reliable. The first two decades of the eighteenth century, the final two decades of Anne Finch's life, did this for 'The Spleen'. With each printing the poem is itself revealed to be somewhat protean, a text with a print history more resistant to being 'fix' $\mathrm{d}[\ldots]$ to remain in one continu'd shape' than the seductive reassurance of the printed page suggests.

Myra Reynolds, whose important edition (1903) introduced Anne Finch to the twentieth century, states that Finch's first poem to be printed was 'The Spleen' in Charles Gildon's New Collection of Poems On Several Occasions (1701). Her authority was probably Thomas Birch, who in his biographical notice of Finch in his expanded translation of Bayle's Dictionary (1741) gives the impression that this was the case (the echoing of Birch's epithet 'considerable' by several later writers attests to his influence). ${ }^{6}$ Gildon's Miscellany was a popular collection of poetry by courtiers such as the Earl of Dorset, Charles Sedley, John Dryden, Nicholas Rowe, '[a]nd Several Other Eminent Hands.' Advertised on the title page as a 'first' edition, the anthology was an amended and much expanded follow-up to a verse miscellany that Gildon had edited in 1692. The 1701 anthology was re-issued with a new title page the same year, and again in 1716 as a 'second edition' with another cancel title page.

Subsequent twentieth-century studies of Finch's career follow this first printing of 'The Spleen ... by a Lady' in Gildon's Miscellany with a second. This is a pamphlet, printed in 1709 by the somewhat notorious Henry Hills. Here the poem appeared, again anonymously, as The Spleen, a Pindarique Ode, by a Lady. Together with a Prospect of Death, a Pindarique Essay. ${ }^{8}$ The Prospect of Death, also printed anonymously here, had been published first in 1700 by the author of The Choice, John Pomfret. Reynolds writes that by 1713 , when Winchilsea was preparing her 
volume of verse, 'her Spleen had attained to the dignity of a second edition' which Reynolds identifies in her notes as this pamphlet. ${ }^{9}$ The $C B E L$ and $N C B E L$, as well as most dictionaries of women writers, also notice this 'republication' or 'second edition.'

The text of the poem as it appears in Hills' pamphlet, however, differs from that in Gildon's Miscellany in ways puzzling in a reprint. In a number of instances the diction in the pamphlet varies from that in the 1701 and 1713 versions of 'The Spleen.' In one case the pamphlet reverses the order of a couplet, and in another it omits the section that makes up lines 138-141 in both the first printing and the 1713 version. The explanation is to be found in the existence of a second verse miscellany published in 1701. A Collection of Poems: viz. The Temple of Death, includes 'The Spleen: A Pindarique Ode. By a Lady'. This anthology, an expanded edition of a 1672 collection, is recorded in the Stationers' register for October, $1701 .{ }^{10}$ It underwent a second edition, with considerable changes, in 1702, and a third in 1716. The most interesting aspect of the poem as it appears in the Temple of Death, apart from the fact that it is printed there, is that it varies from the Gildon edition and Finch's Poems in the same ways that Hills' pamphlet edition does. There are many of the same accidentals and shifts in diction, the same inversion of lines forty-five and forty-six, and the same omission of lines 138-141 that occur in the pamphlet and which constitute its most notable differentiation from the versions in Gildon and in Finch's Poems. Evidently, the pamphlet edition of 'The Spleen' is not the first unauthorized printing, since its text conforms so closely to that of the 1701 Temple of Death. ${ }^{11}$

Both internal and external evidence yoke the Temple version of the ode to Hills' pamphlet. The poem printed directly after 'The Spleen' in this anthology is the same one that is coupled with Finch's poem in the 1709 pamphlet - the anonymously printed 'A Prospect of Death: A Pindarique Essay.' John Pomfret's A Prospect of Death however, had also been reprinted in pamphlet form in 1703, and was erroneously attributed to the Earl of Roscommon. ${ }^{12}$ Roscommon is one of the authors who is named on the title page of The Temple of Death collection, because three poems by the earl do appear therein, although 'A Prospect' is itself printed in the anthology without any author's name given. It is likely the 1703 misattribution to nobility, along with their shared pindaric format, and appearance in an anthology from which Hills borrowed many other poems for reprinting, that led to the twinning in 1709 of 'A Prospect' and Finch's 'The Spleen.' As with Finch's ode, the textual variants coincide closely in the 1701 and 1709 printings of Pomfret's pindaric essay, further evidence that Hills used The Temple of Death as his source for both poems. 'The Spleen' exists in two textual traditions, one authorized (GildonWinchilsea), the other unauthorized (Temple of Death-Hills). 
The inclusion of 'The Spleen' in The Temple of Death testifies to a greater readership and popularity than have been estimated. Before the publication of Finch's Poems in 1713, 'The Spleen' was printed not twice but at least four times. There is, moreover, yet another anthology which includes Finch's ode. The Virgin Muse, printed in 1717 and reissued in 1722, has gone unnoticed in Finch scholarship. ${ }^{13}$ Because Finch's own book of verse was reissued four times with cancel title-pages after its initial appearance, this means that the occasions on which 'The Spleen' was brought into the public eye via new editions and re-issues, including her Poems, total no less than thirteen by 1722, rather than the nine times that have been assumed.

Further, the variants that exist in the two 1701 printings of the poem comment on the occasional nature of 'The Spleen' - as a separate entity from Finch's volume of poetry - and on the initially unstable textual condition of Finch's verse. As such, the ode points to the intersection between manuscript circulation and print culture. In Gildon's collection, 'The Spleen' is prefaced by verse from the playwright and poet Nicholas Rowe that reveals a familiarity with Finch's poem, and with another ode by her, 'All is Vanity', which, though composed before Dryden's death in 1700 , was first printed only in 1713 . Rowe's poem serves as a reminder of the select circle who read and possibly critiqued these poems long before they were printed. ${ }^{14}$

Much can be discovered about a poem by the company it keeps. The Temple of Death shares a number of poets with Gildon's collection, and likely represents the efforts of booksellers Daniel Browne and Benjamin Tooke to capitalize on the popularity of the Gildon collection printed only a few months earlier by Peter Buck and George Strahan. ${ }^{15}$ In addition to highlighting the inclusion of poems by the Earl of Dorset, the title pages of both miscellanies boast the names of the courtiers and diplomats George Stepney, George Grenville, Sir Charles Sedley, and poet laureate John Dryden. Gildon's collection also contains works by Sir Fleetwood Shepheard, and Nicholas Rowe, and the Temple includes verse by Charles Montagu, Lord Halifax, Roscommon, Rochester, and Sir George Etherege. We tend to approach the poetry collections of this period as texts that represent often random, even slightly chaotic, accumulative efforts. However, to a large extent the poets that appear in such anthologies comprise a collective that precedes, and exists apart from, the miscellany in which they appear. A poem titled 'To Mr. Granville on his Verses to the King' by Edmund Waller, for example, is followed in the Temple collection by one 'To Mr. Waller: By Mr. Granville.' A dialectic tone is created in the verse miscellany, wherein the poems do not exist in isolation. In a manuscript 'Preface' Finch insisted that: 
itt is still a great satisfaction to me, that I was not so far abandon'd by my prudence, as out of a mistaken vanity, to lett any attempts of mine in Poetry, shew themselves whilst I liv'd in such a publick place as the Court, where every one wou'd have made their remarks upon a Versifying Maid of Honour; and far the greater number with prejudice, if not contempt. ${ }^{16}$

Despite her anxiety, the appearance of poetry by Finch in two collections rich in epistolary verse and courtly subject matter is significant. Hers is only one poem among many, and was evidently composed independently from the immediately cross-referential verse contained in the collections. Still, the poems speak to each other, acknowledge a coterie writing and reading environment, and Anne Kingsmill, later Finch, had a voice in this dialogue and this circle. Like Charles Sackville and George Granville, Finch represents part of the overlap in the two anthologies, a kind of poets' Venn diagram, wherein 'The Spleen' both belongs to the courtly environment, and transcends it.

A manuscript of post-1713 poems by Anne Finch now at Wellesley College, Massachusetts, has among its contents an epistolary piece, in which Finch recognizes her debt to the Duke of Buckingham, John Sheffield (1650-1721):

For none like Sheaffield can the muse support

Who still composes as in Charles's Court

Where high he stood amidst the tunefull choire

The Class to which succeeding wits aspire. ${ }^{17}$

Jean Ellis d'Allessandro reads this reminiscence as Finch acknowledging that she, too, 'still composes as in the days of the Restoration, days in which Sheffield had published his Essay upon Poetry'(1682). ${ }^{18}$ Certainly the passage functions as a reminder of Finch's earlier status as a courtier. Her relationship to Sheffield, though, is important not only because he was a member of the nobility who encouraged her talent while she was at court, but because in 1694 he was made Marquis of Normanby, and it is he whose translation of Philippe Habert's Temple of Death lends its title - and Sheffield's own title - to the 1701 anthology. ${ }^{19}$ Anne Finch had been out of court circles since 1689 , but there is evidently something of that society that continues to inform these printed miscellanies, as well as the inclusion of her verse in them.

As noted, the first printings of Finch's work occurred in various texts in the 1680s and 90s. A broadside, The Prerogatives of Love, was issued anonymously in 1695. In 1696 six religious poems were included in the first volume of Miscellanea Sacra, a collection that underwent a second edition two years later. ${ }^{20}$ Another ode, On the Death of King James II. By a 
Lady was printed on its own in 1701 . We can assume that Finch did not harbour a long-term plan regarding the genres with which she would advance her status as a poet. She was no Milton or Pope, following in the footsteps of the ancients, writing through the georgic to some sort of epic. Wordsworth lamented that: 'Lady Winchilsea was unfortunate in her models - Pindarics and Fables [...]. She seems to have made it a moral and religious duty to control her feelings, lest they should mislead her. $^{21}$

But she does appear to have explored, and challenged herself with a variety of poetic forms as she progressed. The genres she chose were sometimes mocked (to which she testifies in the poem 'The Critick and the Writer of Fables ${ }^{22}$ ) but her range does evince ambition. Her initiation into print proved her to be lyrical and playful, capable of the pastoral conventions of the song. What followed provided evidence of her Anglican piety, distinguishing her from the male courtier-poets who embraced Hobbes's bleak influence. Her ode on James testified to her loyalty and to her former relations with his court. Then 'The Spleen', in Gildon's collection and in the Temple of Death, proved she was not merely proficient at a popular and flexible genre, but also, by association with the other poets represented therein, still a courtly figure.

'The Spleen' is one of the few pieces in either the Gildon or the Temple anthology that is not occasional; many of the other poems are prologues and epilogues to plays, verses on marriages or on other writers' triumphs, and on death - in Temple, Sheffield's title poem, Pomfret's 'Prospect of Death' (which also follows 'The Spleen' in Hills' pamphlet), poems on the deaths of Abraham Cowley and Charles II, and others; in Gildon, verses on the death of the Duke of Gloucester as well as Robert Howard's 'The Fear of Death', and among the three other poems by Finch, a shorter ode on 'Death.' It is this dark theme that Finch's ode shares with the company it keeps; death threatens throughout 'The Spleen', where the poet identifies an ambiguous and fashionable ailment as real and sinister. The concluding lines of the ode address the case of Dr. Richard Lower, the famous physician who studied the circulatory system but who died in relative poverty and isolation. 'Not skilful Lower thy Source cou'd find', the poet tells the spleen, and argues that Lower worked too hard at his explorations,

Till thinking Thee to've catch'd, Himself by thee was caught, Retain'd thy Pris'ner, thy acknowleg'd Slave,

And sunk beneath thy Chain to a lamented Grave. ${ }^{23}$

She does not dwell on lessons to be learned here, for there are none. John Pomfret's 'A Prospect of Death' also describes an illness, a frightening 
deterioration in which 'Our Face is moisten'd with a clammy Sweat', and the blood thickens and slows. Here we can only hope to attain 'the vast Round of Beatific Love' that follows. ${ }^{24}$ In Sheffield's translation, 'The Temple of Death', the speaker is 'a Willing, though a Worthless Sacrifice' to death, because his beloved has already succumbed to a fever. Death is the 'Goddess' that he implores to 'take' his blood. ${ }^{25}$ Although her own explorations of death are more subtle, Finch's ode also captures a profound suffering that is both universal and particular. Margaret Anne Doody notes: "The Spleen" is a poem in which sensations of odd pain are allied to sensations of pleasure. ${ }^{26}$ This, too, finds resonance in the poems that surround Finch's own in the miscellanies. In her resistance to conventional remedies for the spleen, as well as in her refusal to characterize it as an ailment from which women especially suffer, the poet reveals a sophisticated vision that reads well alongside the varied musings of her male contemporaries. The origins of a poetic vision both direct and open to such complications are worth exploring. The text is never entirely divorced from its context, and the print history of this poetry may well provide a clue as to the environment in which such a vision developed.

In March 1728/29 Mary Delany (1700-1788) spoke to Finch's singular popularity in a letter to her sister: 'I am afraid that you will think I set up for a poet, and that is a character that I detest, unless I am able to maintain it as well as my Lady Winchilsea. ${ }^{27}$ Over fifty years later she invoked Finch's name again, this time to a young female acquaintance:

[k]nowing my dear Miss Hamilton's particularity to antiquated dames, I take the liberty of presenting to you the celebrated Countess of Winchilsea; her good sense and delicate sentiments will I am sure recommend her to your favour. ${ }^{28}$

Delany's interest in Finch, like Finch's own poem, implies both a confidence and a kind of anxiety about writing. In 'The Spleen' the speaker complains of her own susceptibility to depression and discouragement. However, Finch's writing suffers from, but is not itself a symptom of, the spleen:

O'er me alas! thou dost too much prevail:

I feel thy Force, whilst I against thee rail;

I feel my Verse decay, and my crampt Numbers fail.

Thro' thy black Jaundice I all Objects see,

As Dark, and Terrible as Thee,

My Lines decry'd, and my Employment thought

An useless Folly, or presumtuous Fault[.... ${ }^{29}$ 
In The Madwoman in the Attic, Gilbert and Gubar conclude of 'The Spleen' that Finch feared that her desire to write was 'crazy, neurotic, splenic.' Her apprehension, they suggest, arose in part from 'Pope's portrayal of her as the foolish Phoebe Clinket' in the play, 'Three Hours after Marriage', which 'had - not surprisingly - driven her into a Cave of Spleen in her own mind..$^{30}$ Recently, Barbara McGovern has countered this argument by pointing out that Phoebe Clinket is considered now to be a compilation of stereotypes about female writers, rather than a direct attack on Winchilsea. McGovern then reads the same passage of the poem as voicing Finch's confidence, and her exegesis is sound. ${ }^{31}$ But the simple fact that 'Three Hours After Marriage' by Pope, Gay, and Arbuthnot was first performed and printed only in 1717 - four years after Finch's own volume of poetry, and sixteen years after 'The Spleen' was first printed - should prevent this kind of anachronistic reasoning.

Clearly there is much in Finch's poetry that continues to invite critical speculation and close reading. The steady increase of literary criticism and of editions, particularly in anthologies, of her verse and that of other seventeenth and eighteenth-century women is encouraging. However, there is also a danger in scholarship that runs before it can walk, and a thorough comprehension of the print history of this one poem speaks to the likelihood that individual works by seventeenth and eighteenth-century women were more widely read than is generally inferred. Patrick Thomas, in his 1990 edition of Katherine Phillips' poetry, claimed that the selections by her in the 1755 anthology, Poems by Eminent Ladies, constituted the first appearance of her poetry in print since 1710. However, the 1717 and 1722 Virgin Muse miscellany, in which 'The Spleen' was reprinted, is titled after Phillip's poem 'The Virgin' and contains four poems by her. The contents of extant miscellanies have obviously not been adequately explored, nor duly noted. That Finch's own volume of poetry appeared only in 1713 suggests a kind of literary contemporaneity with the early works of the young Alexander Pope, whose twocanto version of 'The Rape of the Lock' had appeared in a miscellany the year before. ${ }^{32}$ Manuscript and miscellany sources, however, testify to the fact that she was a prolific writer long before the turn of the century. Our sense both of her career as a poet, and of her poem as a cultural artifact, must be revised with each bibliographical discovery.

Finch's poetry has been revived because it speaks to us, but whom did it address at the turn of the eighteenth century? Placing their trust in earlier researchers, scholars have preserved and reproduced lacunae in the printing history of 'The Spleen' that, minor as they are, do a disservice to the memory of the poet whose works they aim to promote. In a poem composed after 'The Spleen', Finch begins with an ontological equation: 
'Reputation, Love, and Death, / (The Last all Bones, the First all Breath $[\ldots]{ }^{\prime 33}$ Apparently, she knew of what she wrote. The poet's bones rest where they were laid, but the breath of reputation blows more strongly as the misapprehensions of the past are replaced by the findings of a more attentive scholarship. A writer's history can become cluttered with speculation that reflects rather than illuminates the reader, as facts are lost, fall away. Anne Finch did write, and she did publish, more than has been assumed, and the uncommon reputation she was able to realize in her lifetime should not now be diminished.

\section{CHANTEL LAVOIE}

University of Toronto

\section{Notes}

1 Anne Finch, 'The Spleen', Miscellany Poems on Several Occasions (London, 1713) 88-96, 1-5. All poetry by Finch is taken from this edition.

2 William Stukeley, Of the Spleen. Its Description and History, Uses and Diseases, Particularly the Vapours, and Their Remedy (London, 1723).

3 The Letters of William and Dorothy Wordsworth: The Later Years, ed. Ernest de Selincourt, vol. 1, May 10, 1830 (Oxford: Clarendon, 1939) 477. Wordsworth was advising Dyce on who and what to include in Dyce's Specimens of British Poetesses (London, 1827).

4 Germaine Greer, 'Wordsworth and Winchilsea: The Progress of an Error', first printed in The Nature of Identity: Essays Presented to Donald E. Hayden by the Graduate Faculty of Modern Letters (Tulsa: UTP, 1981) 1-13, reprinted in Slip-Shod Sibyls: Recognition, Rejection and the Woman Poet (London: Viking, 1994) 245-58.

5 Anne Messenger, 'Publishing without Perishing: Lady Winchilsea's Miscellany Poems of 1713', Restoration 5 (1981) 27-37.

6 Between 1734 and 1741 Thomas Birch brought out an expanded translation of Pierre Bayle's Dictionaire Historique et Critique (10 vols.). Along with a brief biographical account of Winchilsea, 'The Spleen' is among six poems by her printed in the final volume. Before mentioning Finch's own Poems, Birch states that 'one of the most considerable of the Countess of Winchilsea's Poems was that upon the Spleen ... printed in A New Miscellany of Original Poems ... published by Mr. Charles Gildon at London 1701 in 8vo'. (vol. x: 178). Later admirers like George Ballard, in his Memoirs of Learned Ladies (1752), and Theophilus Cibber and Robert Shiells in their Lives of the Poets (5 vols., 1753) follow Birch's lead in praising the 'considerable' nature of 'The Spleen', as well as noting its initial appearance in 'A new Miscellany of Original Poems ... published by Mr. Charles Gildon at London in 1701' (Ballard, 371; Cibber and Shiells, III: 321). In 1755, thirty-five years after her death, George Colman and Bonnell Thornton concluded the second volume of their anthology, Poems by Eminent Ladies (1755) with twelve 
poems by Finch, including 'The Spleen', which, true to Birchian tradition, they describe as Finch's 'most considerable poem' (II: 286).

7 The publication date given for this edition is 1715 , but some evidence that the anthology was re-issued in 1716 is provided by the inclusion in the middle of the volume of a 24-page miscellany, untitled, that contains a reference to the battle of Sherriff-Muir, which occurred November 13, 1715.

8 The Spleen, a Pindarique Ode, by a Lady. Together with a Prospect of Death, a Pindarique Essay (London, 1709).

9 Reynolds, lvi $416 \mathrm{n}$.

10 The stationers' register records the first edition of Gildon in February 17th, 1700/1701: 'A Colleccion of Poems by sevall hands, most of them with persons of eminent quality... with the first addiccion of these Miscellanies; The Prospect of Death, a Pindaric, to the Memory of Mr. Dryden _ ; A Pindarick on the spleene and many others_ '. The Term Catalogues date the printing of The Temple of Death in the Trinity Term, June, 1701, but there is no mention here of Gildon's collection. Biblioteca Annua, Number 3, places the publication of Gildon's Miscellany later, sometime between March 25, 1701, and March 25, 1702. Curiously, it is in the volume for the previous year, Number 2, March 25, 1700, to March 25, 1701, that $A$ Collection of Poems viz. The Temple of Death is noted. The order of publication, and the fact that Gildon's registry expressly names 'The Spleen' as an addition suggest we might infer that Finch learned of an unauthorized printing in the works, and that she took steps to have a correct text reputably printed.

11 The source may have been indirect, for example a hand-copied version of 'The Spleen' as it appeared in The Temple of Death, though this seems less likely.

12 [John Pomfret], A Prospect of death: a pindarique essay. Written by the Right Honourable the Earl of Roscommon (London, 1704 [1703]).

13 My discoveries of these printings was anticipated by D. G. Neill in 1954, in a bibliographical dissertation at Oxford on Finch. D.G. Neill, 'Studies for an Edition of the Poems of Anne, Countess of Winchilsea, Consisting of a Bibliography of her Poems and a Study of all Available MSS', diss., (Oxford, 1954). Neill did not take steps to publicize his discoveries. The dissertation has been consulted by a few scholars, but with no real interest in the circulation or commercialization of specific texts in which Finch's poems appeared. Nowhere since the dissertation have these printings of 'The Spleen' been mentioned. Anne Messenger has consulted Neill's article, but she does not seem to know about The Temple of Death, or at least she does not distinguish it from (perhaps the second 1701 issue of) Gildon's anthology. Messenger states that " The Spleen" was such a success that it was included in a second collection only a few months after its first appearance, where it was accompanied by three more poems "by the same hand."' It is, in fact, in Gildon's collection, and not The Temple of Death, that three additional poems by Finch follow 'The Spleen', whereas The Temple of Death includes only the pindaric ode. Messenger, 'Publishing without Perishing' 30.

14 Nicholas Rowe, 'Epistle to Flavia, on the sight of two Pindaric Odes on the Spleen and Vanity, Written by a Lady to her Friend', Gildon's Miscellany (London, 1701) 53-59. The 'Epistle' was reprinted in the many editions of Rowe's poems throughout the century, eventually with a footnote identifying the author of 'The Spleen' and 'Vanity.' 
15 Much as Charles Gildon himself hoped to repeat the sucess of Jacob Tonson's several Poetical Miscellanies.

16 Folio MS. 6-12, Reynolds 7-8.

17 'To the Right Honourable Countess of Hartford', The Wellesley Manuscript Poems of Anne Countess of Winchilsea, ed. Jean M. Ellis d'Allessandro (Florence, 1988) 75.

18 D'Allessandro, 'Introduction', Wellesley Manuscript 75.

19 Horace Walpole, A Catalogue of the Royal and Noble Authors of England, Scotland, and Ireland. 4 vols. vol. 3, (London: John Scott, 1806) 90. A number of poems by Sheffield appear in Temple. Another connection is that one of the anthology's first two booksellers, Benjamin Tooke, would in 1713 become the bookseller of Finch's own Poems.

20 Barbara McGovern, Anne Finch and Her Poetry: A Critical Biography (Athens / London: U. of Georgia P., 1992) 70-71.

21 The Letters of William and Dorothy Wordsworth, I: 477.

22 Finch, 'The Critick and the Writer of Fables' 162. Finch's sense of humour as a poet is one of her more admired qualities: 'Weary, at last, of the Pindarick way ... to Fable I descend with soft Delight', 1,3.

23 'The Spleen' 148-159.

24 John Pomfret, 'A Prospect of Death', Temple 419-32, 38, 225.

25 John Sheffield, 'The Temple of Death', Temple 26-42, 60, 249-50.

26 Margaret Anne Doody, The Daring Muse: Augustan Poetry Reconsidered (Cambridge U.P., 1985) 172.

27 Mary Granville Delany, letter to her sister, 17th March, 1728-29, The Autobiography and Correspondence of Mary Granville, Mrs. Delany, ed. Lady Llanover, 3 vols., vol. 1, (London: Richard Bentley, 1861) 197.

28 Delany, letter to Miss Hamilton, May 1, 1782, The Autobiography and Correspondence, III: 85.

29 'The Spleen' 74-80.

30 Sandra M. Gilbert and Susan Gubar, The Madwoman in the Attic (New Haven and London: Yale UP, 1979) 61.

31 Barbara McGovern, Anne Finch and Her Poetry: A Critical Biography (Athens / London: U of Georgia P., 1992) 103-04,172. McGovern demonstrates convincingly Finch's frustration at the ways in which the spleen inhibits her verse, rather than compelling her to write.

32 The notion of a simultaneous rise to fame is reinforced by the importance of Finch having three pastorals appear in Tonson's Poetical Miscellanies in 1709, which marked Pope's first publication with his 'Pastorals'.

33 'Love, Death, and Reputation' 29, 1-2. 